\title{
Task 17 - Use of Acoustic Energy and Humic Acids to Mobilize DNAPLS From the Subsurface
}

\author{
Semi-Annual Report \\ April 1 - September 30, 1998 \\ RECEIVEO \\ MAR 021999 \\ OSTI \\ By \\ Marc D. Kurz; John R. Gallagher \\ Work Performed Under Contract No.: DE-FC21-94MC31388 \\ For \\ U.S. Department of Energy \\ Office of Fossil Energy \\ Federal Energy Technology Center \\ P.O. Box 880 \\ Morgantown, West Virginia 26507-0880 \\ By \\ Energy \& Environmental Research Center \\ University of North Dakota \\ P.O. Box 9018 \\ Grand Forks, North Dakota 58202-9018
}




\section{Disclaimer}

This report was prepared as an account of work sponsored by an agency of the United States Government. Neither the United States Government nor any agency thereof, nor any of their employees, makes any warranty, express or implied, or assumes any legal liability or responsibility for the accuracy, completeness, or usefulness of any information, apparatus, product, or process disclosed, or represents that its use would not infringe privately owed rights. Reference herein to any specific commercial product, process, or service by trade name, trademark, manufacturer, or otherwise does not necessarily constitute or imply its endorsement, recommendation, or favoring by the United States Government or any agency thereof. The views and opinions of authors expressed herein do not necessarily state or reflect those of the United States Government or any agency thereof. 


\section{DISCLAIMER}

Portions of this document may be illegible in electronic image products. Images are produced from the best available original document. 


\section{TABLE OF CONTENTS}

LIST OF FIGURES $\ldots \ldots \ldots \ldots \ldots \ldots \ldots \ldots \ldots \ldots \ldots \ldots \ldots \ldots \ldots \ldots \ldots \ldots \ldots$

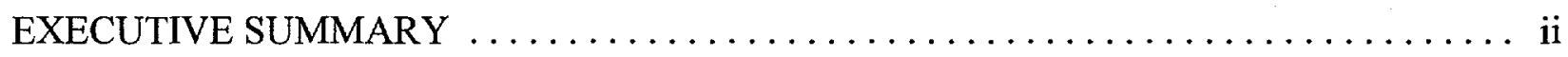

$1.0 \quad$ BACKGROUND/INTRODUCTION $\ldots \ldots \ldots \ldots \ldots \ldots \ldots \ldots \ldots \ldots \ldots \ldots \ldots$

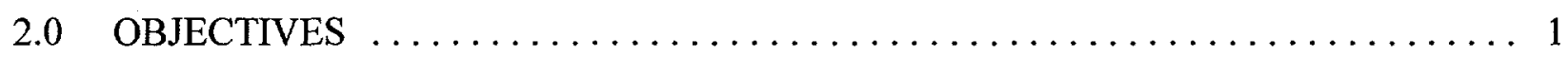

3.0 ACCOMPLISHMENTS $\ldots \ldots \ldots \ldots \ldots \ldots \ldots \ldots \ldots \ldots \ldots \ldots \ldots \ldots \ldots \ldots \ldots \ldots$

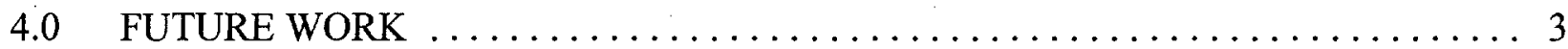

\section{LIST OF FIGURES}

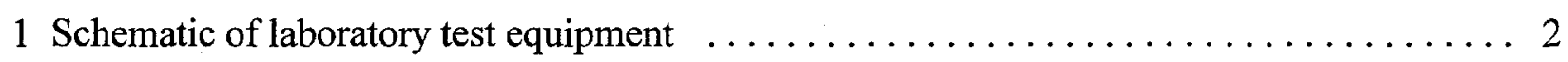

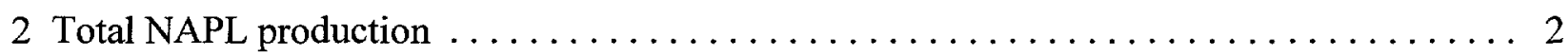

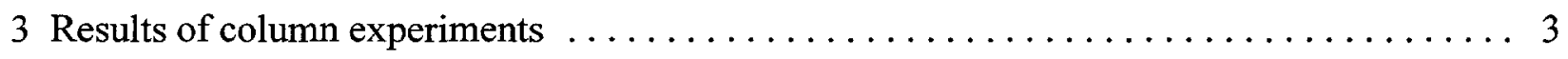




\section{TASK 17 - USE OF ACOUSTIC ENERGY AND HUMIC ACIDS TO MOBILIZE DNAPLS FROM THE SUBSURFACE}

\section{EXECUTIVE SUMMARY}

Weiss Associates of Emeryville, California, is developing and testing a technology intended to improve efficiencies of pump-and-treat systems by mobilizing dense nonaqueousphase liquids (DNAPLs) in the subsurface through the application of acoustic energy. The Energy \& Environmental Research Center (EERC) is evaluating the ability of combined acoustic energy and humic acids to enhance solubility and mobility of DNAPL contaminants as a means to increase efficiency of the Weiss Associates process. Year 1 initiated the characterization of sediments and selection of contaminants, surfactants, and acoustic frequencies to be used in the column experiments. The column tests were initiated and continued into Year 2, with completion expected by November of 1998. Year 3 will investigate the mechanisms within the sample matrix that may control the enhancement affect. 


\section{TASK 17 - USE OF ACOUSTIC ENERGY AND HUMIC ACIDS TO MOBILIZE DNAPLS FROM THE SUBSURFACE}

\subsection{BACKGROUND/INTRODUCTION}

Contamination of the subsurface with dense nonaqueous-phase liquids (DNAPLs) is common throughout the United States, especially at Department of Defense (DOD) and Department of Energy (DOE) sites. These compounds are difficult to remove, as they are poorly soluble in water and tend to stay in pools or sorb strongly to aquifer materials because of their cohesiveness and nonpolarity. Pump and treat is a technology application that offers remediation and contaminant plume containment. However, because of poor mobility and limited solubility, DNAPLs can persist as a contaminant source for years, even decades. Enhanced removal of these compounds from the subsurface requires methods to reduce cohesiveness and improve solubility. Acoustic energy introduced to the subsurface has the potential to disrupt the DNAPL pool and improve mixing. Even with this major improvement, remediation of the contamination may be slow because of poor solubility. Surfactant compounds can also reduce cohesiveness and improve apparent solubility through the formation of micelles containing DNAPL. Commercial surfactants are subject to problems: they are expensive and toxic, sorb to aquifer materials, and exert a biochemical oxygen demand. Nonpolar compounds (DNAPLs) can be sorbed. Humic acids are poorly biodegradable, generally not well adsorbed to aquifer materials, and nontoxic. The combination of acoustic energy and humic acids has high potential for faster, less expensive remediation of subsurface DNAPL contamination when used to enhance pump-and-treat methods or in situ bioremediation.

\subsection{OBJECTIVES}

The specific objective of this task is to evaluate the ability of combined acoustic energy and humic acids to enhance solubility and mobility of DNAPL contaminants.

\subsection{ACCOMPLISHMENTS}

Characterization of sediments and selection of contaminants, surfactants, and acoustic frequencies has been completed. The separate sample column experiments have been initiated, with testing expected to be completed by the end of November 1998. Testing with the acoustic apparatus, as shown in Figure 1, was performed at varied, pulsed, and constant frequencies between 60 and $860 \mathrm{~Hz}$.

Figure 2 illustrates the enhancement effect on total NAPL production for tests with and without acoustic application. 


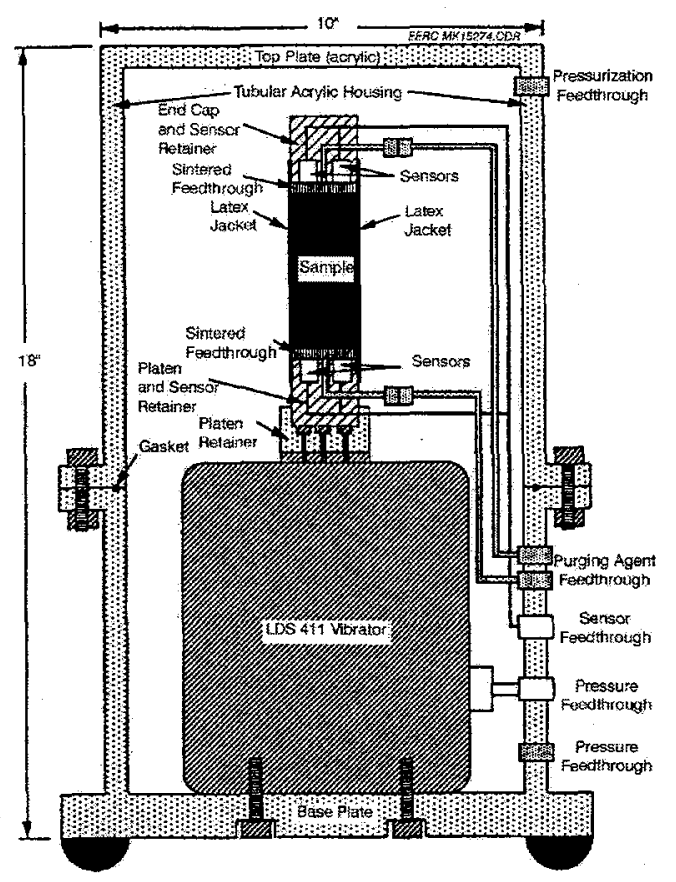

Figure 1. Schematic of laboratory test equipment.

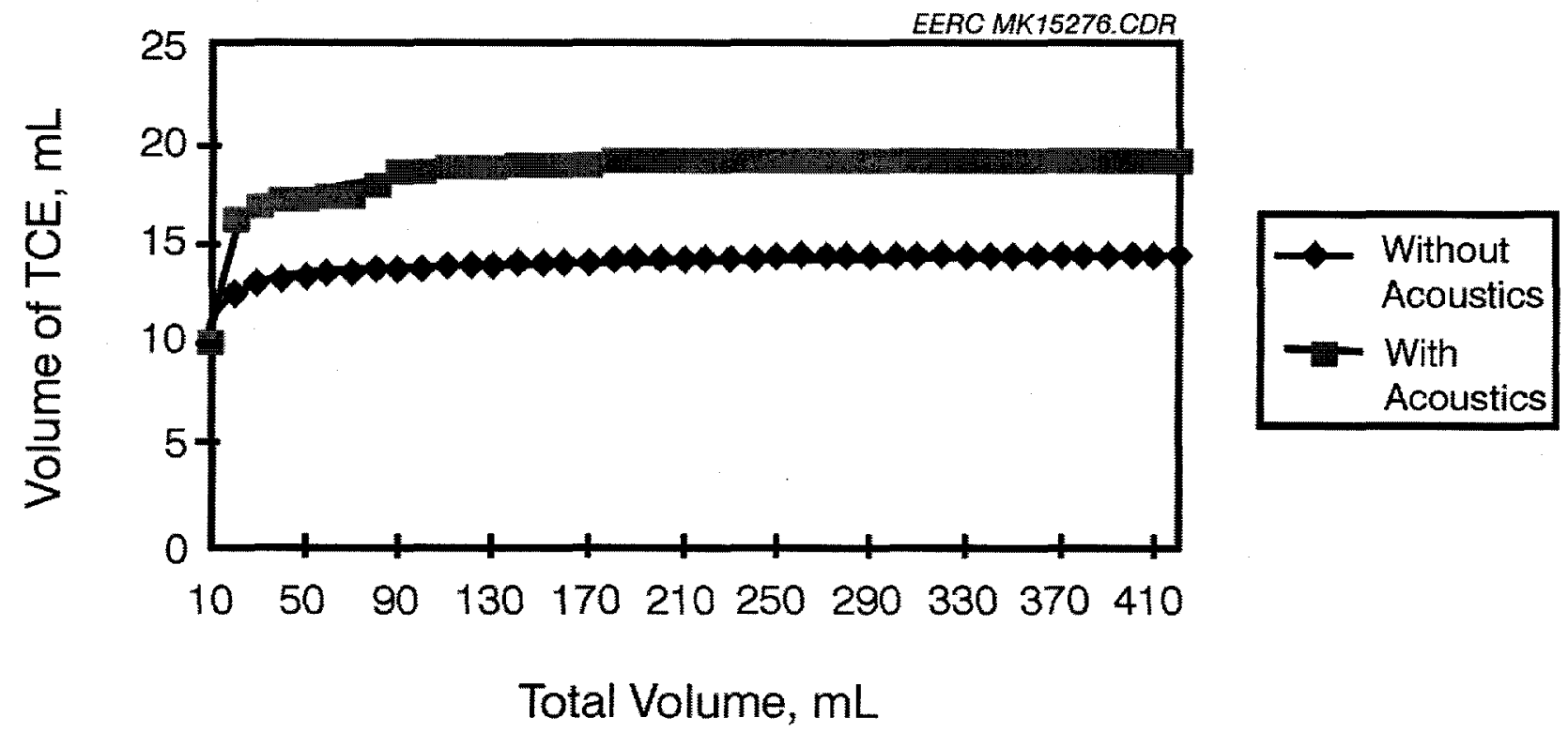

Figure 2. Total NAPL production. 
Preliminary results for the residual sample concentrations, Figure 3, have shown that humates and acoustics alone are comparable in effectiveness to commercial surfactants. Acoustic energy has shown significant enhancement of permeability, DNAPL production, and contaminant removal, with a significant increase in contaminant removal where acoustics and humic acids are used in combination. Further testing to evaluate other combinations of surfactants and acoustics and the optimal level of acoustic frequencies continues.

\section{Residual TCE Concentrations after 100 pore volumes Throughflow}

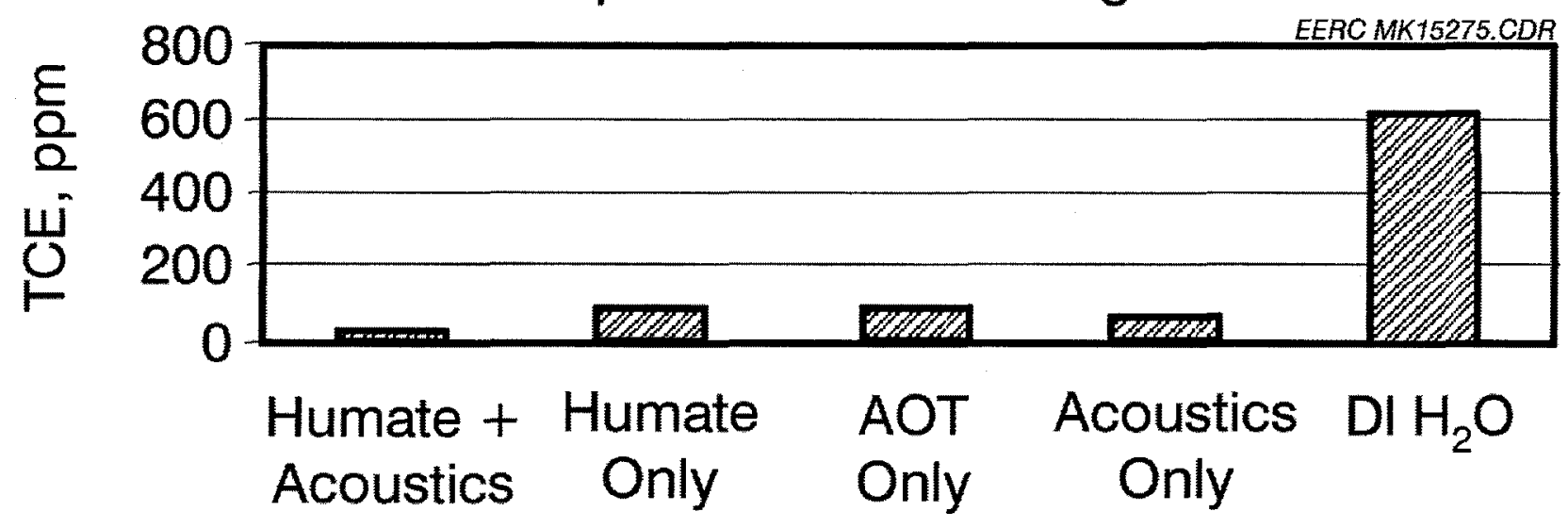

Figure 3. Results of column experiments.

\subsection{FUTURE WORK}

Result compilation and data analysis are expected to be completed by November 30 , 1998. A final report documenting the testing methodology and results will be submitted on this date. 